\section{Providing for nuclear power}

\section{Alvin M. Weinberg}

Nuclear Europe.

Editor-in-chief Peter Holt.

ENS Secretariat, PO Box 2613 ,

CH-3001, Berne, Switzerland.

11/yr. SFr120, \$100.

THE new journal Nuclear Europe is the monthly house organ of the European Nuclear Society (ENS), a consortium of eighteen member nuclear energy societies representing fourteen European countries. A major part of each issue is devoted to a single theme of relevance for the European nuclear scene - for example, nuclear energy developments in France, research on nuclear safety in Europe, or quality assurance and standards in Europe. Each theme is covered by eight or more short semi-technical articles written by European experts. The articles themselves often mix technical developments with political observations - perhaps inevitable in a magazine devoted to a technology under seige.

In addition to the feature articles, each

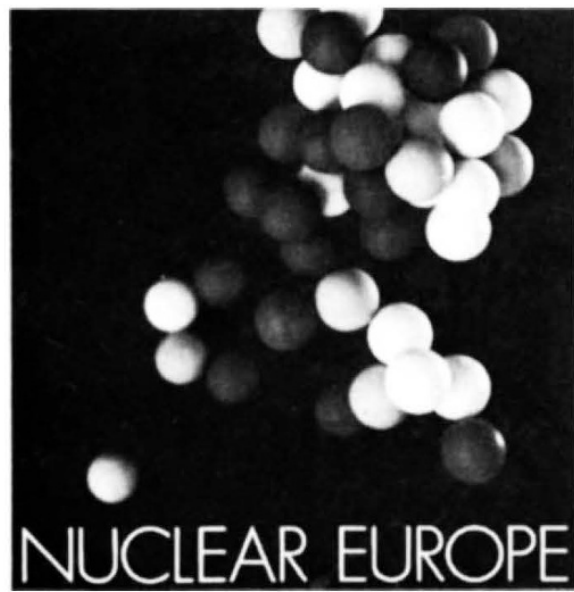

issue carries two dozen short news items. Particulary useful are the items devoted to developments in the Soviet Union and in other centrally planned economies. News of the ENS and its member societies, news from the nuclear research centres and an annotated index of important publications in nuclear energy are also included in each issue. Thus Nuclear Europe covers some of the same technical ground, though in less detail, as Nuclear Engineering International and much the same sort of news but with a European emphasis, as Nuclear News, the counterpart house organ of the American Nuclear Society.

I particularly appreciated the invited editorials by well-known figures in the European nuclear energy community. The editorial tone of Nuclear Europe is therefore set much more by the views of the leaders of the nuclear enterprise than it is by the editor of the magazine. I find this practice more becoming than is the case with Nuclear News, where the editor's own views are much more intrusive. Thus the generally optimistic tone of the feature articles is often muted in the editorials. The elder statesmen, perhaps more than the technically-engaged contributors of the feature articles, seem to be preoccupied with the irrationality of a political process that has become antagonistic toward nuclear energy, even as each issue of Nuclear Europe provides evidence that nuclear energy commercially is doing remarkably well in much of Europe. For any non-members of the European Nuclear Society who wish to follow the European nuclear scene, Nuclear Europe (free to members of ENS) is worth reading.

Alvin M. Weinberg is Director of the Institute for Energy Analysis, Oak Ridge Associated Universities, Oak Ridge, Tennessee.

\section{Distant detection}

\section{Robert N. Colwell}

Soviet Journal of Remote Sensing.

Editor-in-chief Alexander V. Siderenko. Harwood. 6/yr. £283, \$424.

THIS is a cover-to-cover translation of the bi-monthly Russian journal, Issledovanie Zemli iz Kosmosa, which reports on current Soviet research in remote sensing - especially that sponsored by the USSR Academy of Sciences. The translations into English began with the six 1981 issues that comprise volume 3 .

It covers the uses of space technology for investigating the earth's natural resources and emphasizes its applications in geology, oceanography, meteorology, cartography, agriculture, forestry, hydrology, radiotechnology, computer technology, optics, electronics, astronautics and engineering. State-of-the-art assessments are given of the latest theoretical and applied research developments taking place both in the Soviet Union and in certain other countries, such as Cuba and Poland.

Each issue has the following major sections: (1) Application of Space Technology in Earth Sciences and National Economy; (2) Physical Principles, Methods and Equipment for Earth Data Acquisition and Processing; (3) Reviews and Information; (4) News Items; and (5) Synoptics of Forthcoming Papers. Typically, an issue contains between 15 and 20 articles in the catagories (1) and (2) above and there are nearly 200 pages in each issue. The sixth or final issue each year also contains both a title index and an author index for all six issues published during that year. The average delay in publishing these articles after receit is approximately nine months, for the original Russian version, and 27 months for the English translation.
Much of the work reported upon greatly overlaps work that is being performed in the United States and elsewhere. The remarkable similarity of findings helps document the global applicability of various remote sensing-based techniques for the inventory and management of natural resources. Therefore this journal, reporting Russian work is complimentary to, rather than competitive with, other remote sensing journals.

Robert N. Colwell is Professor of Forestry and Associate Director to the Space Sciences Laboratory, University of California, Berkeley.

\section{Current awareness}

\section{A. Holmes-Siedle}

\section{Sensors and Actuators:}

International Journal Devoted to

Research and Development of

Solid- state Transducers.

Editor S. Middehoek.

Elsevier Sequoia. 8/yr. \$210.85, SFr430.

Ferroelectrics: Letters Section.

Editors I. Lefkowitz and G.W. Taylor.

Gordon \& Breach. 10/yr. £130, \$200.

Applied Physics Communications.

Editors Allen M. Hermann and John A.

Woollam.

Dekker. $4 / y r . \$ 55$.

A publication devoted to sensor principles is definitely needed. Sensors and Actuators claims to be the "first specific journal on solid state transducers" and indeed appears to be so. The compact but international board of this journal contains a good proportion of names wellknown in the sensor field (exactly, half are American, with a Dutch editor-in-chief) and this should ensure a supply of highquality papers.

The word activators suggests solenoidoperated mechanical devices but these are in a sense, relics of the past and editorial preference will lean towards solid-state electronic generators of mechanical, optical or magnetic impulses. Only a small variety of this type has yet been invented. This includes light emitting diodes, liquidcrystal displays, micro-switches and piezoelectric pumps. Therefore, solid-state sensors may for a while dominate the discussion.

The production and format are of high quality. The content of the first three volumes has tended to be chemical, not only because the entire first volume consists of the proceedings of a conference on chemically-sensitive devices but also because there are several specialists in this field on the editorial board. However, it is unlikely that it will go overboard in this direction; for one thing the offer of papers in other sensor fields is likely to be heavy 